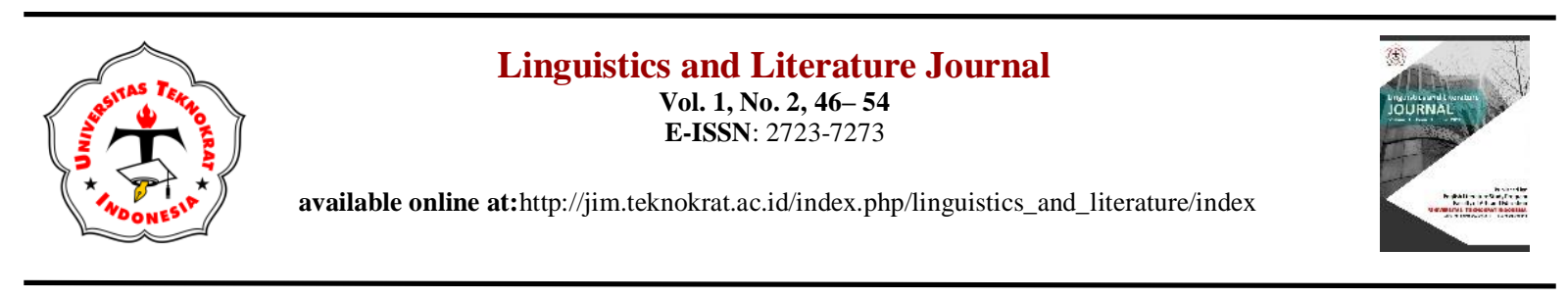

\title{
METAPHORICAL EXPRESSIONS IN EMILY DICKINSON'S POEMS
}

\author{
Lola Cenita ${ }^{1}$, Ely Nurmaily ${ }^{2}$ \\ UniversitasTeknokrat Indonesia ${ }^{1,2}$
}

cenitalola@gmail.com ${ }^{1,}$ elynurmaily@teknokrat.ac.id ${ }^{2}$

Received: (October 2020)

Accepted: (November 2020)

Published: (December 2020)

\begin{abstract}
The poem has the role of the media to deliver the author's opinion, messages, and feeling towards certain phenomena to the readers by using literary language. The idea of those poems needs to be interpreted by the readers and it is dealing with meaning. Problems occur when there is the literary language used by the author since not all the reader can understand the implicit meaning inside the poems which certainly used figurative language, especially metaphor. Thus, the study entitled Metaphorical Expressions in Emily Dickinson's Poems aimed to find the metaphor inside three poems by Emily Dickinson entitled I Felt a Funeral in My Brain, Because I could Not Stop for Death and I Heard a Fly Buzz - when I Died. This study also aimed to identify the implicit meaning behind those metaphors. In analyzing the data, the researcher used the metaphor theory proposed by Lakoff and Johnson, they are structural metaphor, ontological metaphor, and orientational metaphor. To answer the second research question, the researcher used the theory of meaning by I. A Richard. This study used a descriptive qualitative method and stylistic approach, in which the researcher focuses on the aesthetic function of the language. In this research, the researcher found 17 metaphorical expressions divided into 5 types of metaphor there are: entity metaphor 4 data, structural metaphor 5 data, orientation metaphor 1 data, container metaphor 1data and personification 6 data.
\end{abstract}

Keywords: Emily Dickinson, Gold Rush, Semiotic, Socio-historical, Symbol

\section{INTRODUCTION}

A language is an important tool of communication (Amelia, 2016). Language is also an important tool to deliver an idea and desire (Rido, 2020). Besides that, language can also be used to convey an argument that can be stated in a text and speech (Unggul and Gulo, 2017). In a text, the content and the meaning can be conveyed through a language (Kuswoyo and Siregar, 2019). Yousif (2018) argues that language is divided into two groups, which are everyday language and literary language. The literary language is more artistic compare to ordinary language that we used in daily conversation. The aim of using the literary language is to convey the idea, deep feeling, message, and image to the audience (Setri and Setiawan, 2020). A poem can be defined as one of the literary works that come from the expression of poets. A poem is a kind of language that says more intensely than ordinary language (Peck and Koyle, 1984). This research is about analyzing poems by Emily Dickinson using a stylistic approach focusing on metaphorical expressions. The researcher used theories from Lakoff and Johnson (2003) for the metaphor and I.A Richard (1982) to find the meaning of the metaphor. Those three poems are I Felt a Funeral in My Brain, Because I could Not Stop for Death and I Heard a Fly Buzz - when I Died that taken from the book entitled Selected Poems and Letters of Emily Dickinson that was published by Anchor Books in New York, 1959. The use of metaphors and the uniqueness of the themes used by Dickinson in her poems are worth further investigation in the field of literature. Thus, this study aims to analyze the types of metaphor used in selected poems by Emily Dickinson and to find out what are the implicit meanings that represent in Emily Dickinson's selected poems that used the death theme.

Research conducted by Cahyo (2009) entitled "The Perception of Love and Death of Emily Dickinson Seen on her Selected Poem" using found that the selected poems by Emily Dickinson's poems come from the feeling of the speaker losing the people she loves. Next, a research conducted by Ulfa (2016) entitled The Metaphor Used in Anne Bradstreet's Poem found that 27 lines of Anne Bradstreet's poem contain the metaphor. 8 lines include in anthropomorphic metaphor, and 2 lines include in synesthetic metaphor. To add, a research conducted by Putri (2013) entitled 'Translation of Metaphorical Expressions in Andrea Hirata's Edensor found that there two kinds of metaphor in Edensor novel, they are dead metaphor and life metaphor. She has proven that there are 9 techniques applied to translate the metaphorical expressions. Next, is a study conducted by Harata and Hamsia (2016) entitled “An Analysis of Metaphor in Maya Angelou's "Caged Bird" and "I Still Rise” Poem”. The result 
found that there are three types of metaphor found in Maya Angelou's selected poems. There are live metaphor conceptual, mixed metaphor, and poetic metaphor. Another previous study entitled An Analysis of Metaphor in Emily Dickinson's Poems written by Syarwani (2017) found that ten of Emily Dickinson's poems contains 36 metaphorical expressions. Thus, the researcher can adapt the method and the way he collects the data from the poems as well as the step to analyze the metaphor.

\section{METHOD}

In this research, the researcher used a descriptive qualitative method that the researcher believes is suitable for this research since the type of research in this study is a textual analysis that intended to analyze the metaphor used by Emily Dickinson (Samanik and Liana, 2016). It is can be concluded that the method that we will use is to find out, define, and describe the finding that is analyzed by the researcher.

\section{FINDINGS AND DISCUSSION}

In this study, the researcher applied the theory of metaphorical expressions proposed by Lakoff and Johnson (2003) and the theory of meaning proposed by I.A Richard (1982).

\section{Poems Presentation}

Poem 1: I Felt a Funeral in my Brain

Ifelt a Funeral, in my Brain,

And Mourners to and fro

Kept treading - treading - till it seemed

That Sense was breaking through-

And when they all were seated,

A Service, like a Drum -

Kept beating - beating - till I thought

My mind was going numb -

And then I heard them lift a Box

And creak across my Soul

With those same Boots of Lead, again,

Then Space - began to toll,

As all the Heavens were a Bell,

And Being, but an Ear,

And I, and Silence, some strange Race,

Wrecked, solitary, here -

And then a Plank in Reason, broke,

And I dropped down, and down -

And hit a World, at every plunge,

And Finished knowing - then -

Emily Dickinson's poem entitled I Felt a Funeral in my Brain is the poem in which Dickinson shares about the experience of the speaker during facing her collapse. The speaker tries to explain that she is worried about how she died or even she is dying inside already. The mourners are all seated, indicate a quiet moment. While the sound of the drum symbolizes the step of death is already approaching her. The third stanza visualizes the atmosphere during the burial ceremony. The speaker could hear the creaking sound of the coffin that is carried by the mourners.

Poem 2: Because I could Not Stop for Death

Because I could not stop for Death-

He kindly stopped for me-

The Carriage held but just Ourselves And Immortality. 
We slowly drove - He knew no haste

And I had put away

My labor and my leisure too,

For His Civility -

We passed the School, where Children strove

At Recess - in the Ring -

We passed the Fields of Gazing Grain-

We passed the Setting Sun-

Or rather - He passed Us -

The Dews drew quivering and Chill-

For only Gossamer, my Gown -

My Tippet-only Tulle-

We paused before a House that seemed

A Swelling of the Ground-

The Roof was scarcely visible -

The Cornice - in the Ground-

Since then - 'tis Centuries - and yet

Feels shorter than the Day

I first surmised the Horses' Heads

Were toward Eternity -

Emily Dickinson's poem entitled Because I could Not Stop for Death expresses the poet's perspective on death. This poem which consists of six stanzas clearly shows that the main theme of this poem is death. In the first stanza, Emily Dickinson personified death as a gentleman who takes her for a ride, probably to the afterlife. In the next stanza, she explained that they slowly drove. This is an expression that the death who is taking her is polite and calm. While in the last stanza, Emily Dickinson explains that the century is felt shorter than the day. It is indicated that the poet realizes there is no price to pay for death. She also expressed her idea in which death is not something to be feared but rather embraced.

Poem 3: I Heard a Fly Buzz - when I Died

I heard a Fly buzz - when I died -

The Stillness in the Room

Was like the Stillness in the Air -

Between the Heaves of Storm -

The Eyes around - had wrung them dry And Breaths were gathering firm

For that last Onset - when the King

Be witnessed - in the Room -

I willed my Keepsakes - Signed away

What portion of me be

Assignable - and then it was

There interposed a Fly -

With Blue - uncertain - stumbling Buzz -

Between the light - and me -

And then the Windows failed - and then

I could not see to see - 
Emily Dickinson's poem entitled I Heard a Fly Buzz - when I Died is described the condition of the dying speaker in the room. The speaker repeated the word stillness to explain the motionlessness of death and the anticipation of death come. This can also be described as the event to accept into heaven and meeting God. The second stanza discusses the condition of people who are waiting for dying people, and they cry until they can't cry anymore. This poem also describes the Victorian tradition to give all the keepsakes to others when someone is about to die. The last stanza explains about blue color, which probably symbolizes heaven and the dying speaker is can't see anymore, which indicates she has died already.

\section{The Kinds of Metaphors of the Selected Poems}

\begin{tabular}{|c|l|l|}
\hline Line & \multicolumn{1}{|c|}{ Line } & \multicolumn{1}{|c|}{ The kind of metaphor } \\
\hline $\mathbf{1}$ & Ifelt a Funeral, in my Brain, & Structural metaphor \\
\hline $\mathbf{4}$ & That Sense was breaking through - & Entity metaphor \\
\hline $\mathbf{1 0}$ & And creak across my Soul & Structural metaphor \\
\hline $\mathbf{1 6}$ & Wrecked, solitary, here - & Entity metaphor \\
\hline $\mathbf{1 8}$ & And I dropped down, and down - & Orientational metaphor \\
\hline $\mathbf{2 0}$ & And Finished knowing - then - & Structural metaphor \\
\hline
\end{tabular}

Table 2 The metaphor used in Ifelt the funeral in my dreams

\section{A. I felt a Funeral, in my Brain,}

Consider "I felt a Funeral, in my Brain". How can the activity that we can see or do can be felt in our mind? How does "funeral" apply to feel? In this case, there is a basic conceptual metaphor, in which one concept is being metaphorically structured in terms of another concept. The structural metaphor has a certain concept, which is the concept of love, the concept of social organization, and the concept of life. In this line, the activity is structured as a feeling, which has a concept ACTIVITY IS FEELING, where our body is not doing that activity but our mind can feel it. So this sentence can be categorized as a structural metaphor with conceptual metaphor ACTIVITY IS FEELING.

\section{B. That Sense was breaking through -}

This sentence contains an ontological metaphor, in which the abstraction of sense represented as something concrete which is a person that can "breaking through" something, this metaphor called as entity metaphor that represents the concept of the "sense" as the physical object that metaphorically structured as a person that try to breaking through the door or anything in front of them.

\section{And creak across my Soul}

The word "creak" in the line "And creak across my Soul" refers to the previous line which is "And then I heard them lift a Box". This metaphorically describes the creaking sound that is supposed to be heard by our ear can be felt by the soul. In this case, there is a basic conceptual metaphor in which one concept is being metaphorically structured in terms of another concept. In this line, the sound is structured as a feeling which has a concept SOUND IS FEELING. Where our ear is not heard that sound but our soul can feel it. So, this sentence can be categorized as a structural metaphor with a conceptual metaphor SOUND IS FEELING.

\section{Wrecked, solitary, here -}

The word "wrecked" in this line refers to the previous line which is "And I, and Silence, some strange Race". This sentence contains an ontological metaphor, in which the abstraction of "silence" represented as something concrete which is a person that can "wrecked" something, this metaphor called as entity metaphor that represents the concept of the "silence" as the physical object that metaphorically structured as a person that tries to wrecked the solitary that contains in the poem. 


\section{E. And I dropped down, and down -}

And I dropped down, and down - contains the orientational metaphor, in which the metaphor that not used structure as one concept in terms of another but instead organizes a whole system of concepts concerning one another. This orientational metaphor is mostly related to spatial orientation. In this case, the metaphorical expression is up and down. This metaphorical expression provides the concept of spatial orientation. We know the fact that the concept of "happy" is oriented to English expressions like "I'm feeling up today". The phrase "happy is up" is the spatial orientation of "up and down", so we can assume that "Happy is up" while "sad is down". The line "and I dropped down, and down" shows the fact that the poet is sad and falls into depressions.

\section{F. And Finished knowing - then -}

This line contains the structural metaphor in which the word "finished" refers to the life journey of the poets. This metaphorically describes that the life lived by the women is already finished. It indicates that life is finished, when someone is born is considered as a start while when someone dies is considered as the finish. In this case, there is a basic conceptual metaphor in which one concept is being metaphorically structured in terms of another concept. In this line, life is structured as a journey which has a concept LIFE IS JOURNEY.

\begin{tabular}{|c|l|l|}
\hline Line & \multicolumn{1}{|c|}{ The Poem } & \multicolumn{1}{|c|}{ The Kind of Metaphor } \\
\hline $\mathbf{1}$ & Because I could not stop for Death - & Entity metaphor \\
\hline $\mathbf{2}$ & He kindly stopped for me - & Personification \\
\hline $\mathbf{3}$ & The Carriage held but just Ourselves - & Container metaphor \\
\hline $\mathbf{5}$ & We slowly drove - He knew no haste & Personification \\
\hline $\mathbf{8}$ & For His Civility - & Personification \\
\hline $\mathbf{1 3}$ & Or rather - He passed Us - & Personification \\
\hline $\mathbf{1 4}$ & The Dews drew quivering and Chill - & \\
\hline $\mathbf{2 2}$ & Feels shorter than the Day & Personification \\
\hline
\end{tabular}

Table 2 The metaphor used in Because I could Not Stop for Death

\section{A. Because I could not stop for Death -}

This sentence contains an ontological metaphor. This metaphor represents the concept as the concrete physical object, in which the abstraction of "death" is represented as something concrete that has a characteristic of a man that wants to pass by and can't be stopped. This metaphor is called an entity metaphor that represents the concept of "death" as the physical object that is metaphorically structured as a person or man.

\section{B. He kindly stopped for me -}

This line contains the personification in which the nonhuman experience human motivations, characteristics, or activities. In this case, the word "he" that refers to the first line which is "Because I could not stop for Death" contains the personification because the "death" experiences human activity which is trying to stop the women in the poem who metaphorically describe as a man.

\section{The Carriage held but just Ourselves -}

This line contains the container metaphor, in which the expressions of the word "carriage" have a concept of being the container. Just like the container, the concept has inside and outside, and it can hold something like the real container. In this case, the carriage describe can hold "ourselves" which refers to the women in the poem, and "he" which is the death itself. Thus, this line is considered as the container metaphor that includes an ontological metaphor.

\section{We slowly drove - He knew no haste}

This line contains the personification, in which the nonhuman experience human motivations, characteristics, or activities. In this case, the word "he" that refers to the first line which is "Because I could not stop for Death" contains the personification because the "death" experiences human activity which is "slowly drove and no haste" when they want to get on the carriage. 


\section{E. For His Civility -}

This line contains the personification, in which the nonhuman experience human motivations, characteristics, or activities. In this case, the word "his" that refers to the first line which is "Because I could not stop for Death" contains the personification because the "death" experiences human characteristic which has civility. It is described by the woman in the poem that the "death" which she considers as the man treats her with all of his civility and very gentle.

\section{F. Or rather - He passed Us -}

This line contains the personification, in which the nonhuman experience human motivations, characteristics, or activities. In this case the word "he" that refers to the previous line which is "school", "fields", and "setting sun" contain the personification because those words that are not a human being but can experience human activity that can be passed something. It is described by the woman in the poem that the women and the man passed the "school", "fields", and "setting sun" or rather "school", "fields", and "setting sun" that passed them, this shows that this line contains the ontological metaphor which is personification.

\section{G. The Dews drew quivering and Chill -}

This line contains the personification, in which the nonhuman experience human motivations, characteristics, or activities. In this case, the word "dews" contains the personification because the dews itself metaphorically describe experience human activity which is quivering and Chill. Thus, this shows that this line contains the ontological metaphor which is personification.

\section{H. Feels shorter than the Day}

This line, "Feels shorter than the Day" contains a structural metaphor, in which one concept is being metaphorically structured in terms of another concept. The structural metaphor has a certain concept which are the concept of love, the concept of social organizations, and the concept of life In this line, the "day" is structured as a "journey", which has a concept DAY IS JOURNEY that can be felt whether it is long or short like a journey. So this sentence can be categorized as a structural metaphor with conceptual metaphor DAY IS JOURNEY.

\begin{tabular}{|c|l|l|}
\hline Line & The Poem & The Kind of Metaphor \\
\hline $\mathbf{5}$ & The Eyes around - had wrung them dry - & Entity metaphor \\
\hline $\mathbf{6}$ & And Breaths were gathering firm & Personification \\
\hline $\mathbf{1 5}$ & And then the Windows failed - and then & Structural metaphor \\
\hline
\end{tabular}

Table 4.2.3The metaphor used in I Heard a Fly Buzz - when I Died

\section{A. The Eyes around - had wrung them dry -}

This line contains the entity metaphor. Entity metaphor is the metaphor that represents the concept as the concrete physical object. In this case, the concept of "eyes" is metaphorically structured as "wet clothes" that can be wrung. Thus, that sentence can be categorized as the part of orientational metaphor which is the entity metaphor.

\section{B. And Breaths were gathering firm}

The line "And Breaths were gathering firm" is contains the personification, in which the nonhuman experience human motivations, characteristics, or activities. In this case, the abstraction of "breaths" metaphorically structured as a person in a gathering or a meeting. Thus, this line can be categorized as a part of orientational metaphor which is personification.

\section{A. And then the Windows failed - and then}

The line "And then the Windows failed - and then" is connected to the line afterward which is "I could not see to see" that contains the structural metaphor in which the basic conceptual metaphor in one concept is being metaphorically structured in terms of another concept. In this line, the concept of "window" is metaphorically structured as an "eyes" that can see anything. Thus, this line has a concept EYES IS WINDOWS. Where the poet is not directly saying that her eyes can't see anymore, but using the concept of "windows" to replace it. So this sentence can be categorized as a structural metaphor with conceptual metaphor EYES IS WINDOWS. 


\section{The Implicit Meaning of The Metaphors}

In recent years, the existence and importance of the problem of "meaning" have been generally admitted and needs serious attention. Lyons defined meaning as the idea or concept which can be transferred from the mind of the listener by embodying them as they were in the form of one language or another, (1981:136). As I. A Richard stated in his book entitled The Meaning of Meaning, meanings essentially personal, what anything means depends., on who means it, (1982:161). Larson argues that there are two types of meaning, there are explicit meaning, which easily can be understood, and implicit meaning, something that is not expressed clearly, (1998:43). Due to the research questions that have been formulated by the researcher, the main focus of this study is on the implicit meaning of the metaphorical expressions found in Emily Dickinson's poems. This second research question depends on the finding of the first research question which are 17 metaphors found in Emily Dickinson's poems. The researcher will elaborate on the implicit meaning of each metaphor as follows:

\section{Ifelt a Funeral, in my Brain}

\section{A. I felt a Funeral, in my Brain}

The meaning of this metaphorical expression is "depressions". In which the word "funeral" here is not the literal meaning of funeral, however, it refers to the condition of someone that feels messed up, sad, and the feeling was destroyed like when we feel the atmosphere at the funeral. This statement is also strengthened by the result of someone's study about the theme of this poem, that this poem is ambiguous, in which as the reader we can decide what our perspective towards the poet is. Whether the poet feels depressed or feels like she dying inside. Thus, this metaphorical expression shows us how the poets feel so depressed and messed up by using the word "funeral" that metaphorically structured as depression.

\section{B. That Sense was breaking through -}

This metaphorical expression has a meaning that the poets want to escape from reality. The word breaking through that refers to the sense is indicate that the poet is no longer able to survive in that situation which full of pressure. This metaphorical expression also correlates with the previous one that still describes the condition of the poet.

\section{And creak across my Soul}

The meaning of the metaphorical expression "and creak across my soul" is the thing that bothering her mind. The poet tries to tell us that something that gives her the pressure is bothering her by not say it but rather used the phrase creak across my soul that metaphorically structured as something that bothering her mind and emotion.

\section{Wrecked, solitary, here -}

Wrecked, solitary, here - is almost has a similar meaning with the previous metaphorical expression which is "and creak across my soul". It tells the thing that bothering her serenity. The poet tries to tell us about her condition that the pressure is breaking the silence by not say it, but rather used the phrase Wrecked, solitary, here that metaphorically structured as something that bothering her condition.

\section{E. And I dropped down, and down -}

This metaphorical expression means depression based on the whole context of the poem. In which the word "down" indicates the emotional condition of the poet that feels so sad and falls into depression.

\section{F. And Finished knowing - then -}

This metaphorical expression means that the poet already gives up. This metaphorically describes that the life lived by the women is already finished. It depends on the reader whether they want to consider the poet is dead or the poet gives up and falls into depression.

\section{Because I could Not Stop for Death}

\section{A. Because I could not stop for Death -}

This metaphorical expression has a meaning that everyone will die. The poet tries to highlight the reality that as a human being who lives in this world are cannot escape from the fact that everyone will die, because death cannot be stopped, but must be accepted. 


\section{B. He kindly stopped for me -}

This metaphorical expression implies dying in peace. In this case, the word "he" that refers to the "death" is being described in this poem approaching the poet to face the death in a very good way like a man who treats a woman politely. The poet tries to convey the idea of dying in peace by not tell it in the literal language, but rather used the metaphor "he (death) kindly stopped for me". This metaphorical expression shows that death that fetches the poet is very peaceful.

\section{The Carriage held but just Ourselves -}

The Carriage held but just Ourselves - implies that we die alone. Dying alone means we cannot ask anyone or our beloved one to help us and accompany us in facing death. They may be sitting around us but they can't stop the death itself. The poet also tries to explain that we die in solitude, go to another world with loneliness and there is only eternity after that.

\section{We slowly drove - He knew no haste}

The metaphorical expression from "We slowly drove - He knew no haste" still correlates with the previous one that implies dying in peace. in this case, the words "slowly drove" This metaphorical expression shows that her journey to face death is not rushed which means that the death that experience by the poet very peaceful.

\section{E. For His Civility -}

The metaphorical expression from "For His Civility - " still correlate with the previous one which is "He kindly stopped for me -" and "We slowly drove - He knew no haste "which implies dying in peace. In this case, the word "civility" is metaphorically structured about peace. The women in the poem try to illustrate that the way death comes to her is like the way of a man that treats women with civility.

\section{F. Or rather - He passed Us -}

This metaphorical expression implies about time is running so fast. The woman in this poem explained in the previous line that she felt like she had just passed her school, her fields, and even the setting sun. but then she thinks that it is not herself who is passing through all of those things. But that is all those things that pass through her which metaphorically shows that time is running every day and everything in this life seems so short.

\section{G. The Dews drew quivering and Chill -}

This metaphorical expression has a meaning of sweating because nervous. Imagine a situation when we face something big in our life which makes us sweats because we feel nervous. In this case, Emily Dickinson tries to explain her situation when she feels nervous by using the concept of dew that is metaphorically structured as sweating.

\section{H. Feels shorter than the Day}

The metaphorical expression of "Feels shorter than the Day" has the implicit meaning that life is too short. This statement is strengthened by the previous line that the poet tries to explain even the centuries feel shorter than the day.

\section{CONCLUSION}

The researcher concludes that the result of the metaphorical expressions in Emily Dickinson's selected poems shows 17 findings for the types of metaphor in Emily Dickinson I Felt a Funeral in My Brain, Because I could Not Stop for Death and I Heard a Fly Buzz - when I Died. Those 17 metaphorical expressions are divided into 5 types of metaphor there are entity metaphor 4 data, structural metaphor 5 data, orientation metaphor 1 data, container metaphor 1data and personification 6 data. According to the data found in three selected poems by Emily Dickinson, the researcher concludes that personification was dominant in her poem.

Regarding the second research question about the implicit meaning of metaphor found in Emily Dickinson's poems, I Felt a Funeral in My Brain, Because I could Not Stop for Death and I Heard a Fly Buzzwhen I Died, the researcher conclude that the implicit meaning of metaphorical expressions is talking about death and pressure. The poems convey almost the same message. There is also information about life inside the poems. However, it can be indicating that the dominant message of those three poems is talk about death.

From the analysis that has been done, it can be concluded that metaphor has an important role in the poem due to the aesthetic effect. That's also becoming the reason why the poet chooses to use metaphor in their literary 
works. Metaphors can make the poem more interesting to be read and give the image to the reader to imagine the idea that the poets try to convey differently. It also helps the reader to capture the idea by knowing the implicit meaning of each metaphor to understand the hidden message of each metaphorical expression contains in the poems.

\section{REFERENCES}

Amelia, Dina. (2016). Indonesian literature's position in world literature. Teknosastik: Jurnal Bahasa dan Sastra, $14(2), 1-5$.

Cahyo, Sandi Adi. (2009). The Perception of Love and Death of Emily Dickinson Seen on her Selected Poems. Yogyakarta: Sanata Dharma University.

Dickinson, Emily. (1983). I Felt a Funeral in My Brain. Cambridge: Harvard University.

Dickinson, Emily. (1999). Because I could Not Stop for Death. Cambridge: Harvard University.

Dickinson, Emily. (1999). I Heard a Fly Buzz - when I Died. Cambridge: Harvard University.

Harata, Akbar Pradana \& Hamsia, Waode. (2016). An Analysis of Metaphor in Maya Angelou's "Caged Bird" and "Still I Rise" Poems: Teaching of English Language and Literature Journal.2016.

Kuswoyo, Heri \& Siregar, R. A. (2019). Interpersonal metadiscourse markers as persuasive strategies in oral business presentation. Lingua Cultura,13(4), 297-304

Lakoff, George \& Johnson, Mark. (2003): Metaphors we live by. Chicago: The University of Chicago.

Peck, John \& Koyle, Martin. (1984). Literary Terms and Criticism. London: Macmillan Education Limited.

Putri, Yolanda Cynthia. (2013). Metaphorical Expressions in Andrea Hirata's and John Colombo's Edensor. Yogyakarta: UNY.

Richard, I.A. (1982). The Philosophy of Rhetoric. Oxford: Oxford University.

Rido, Akhyar. (2020). Why they act the way they do? Pedagogical practices of experienced vocational English language teachers in Indonesia. International Journal of Language Education, 4(1), 24-37

Samanik \& Lianasari, Fita. (2016). Antimatter technology: The Bridge between Science and Religion toward Universe, Creation Theory illustrated in Dan Brown's Angles and Demons. Teknosastik: Jurnal Bahasa dan Sastra, 14(2), 18-27.

Syarwani, Habib. (2017). An Analysis of Metaphor in Emily Dickinson's Poems. Ponorogo: IAIN Ponorogo.

Setri, Teta Irama \& Setiawan, Dwi Budi. (2020). Matriarchal Society in The Secret Life of Bees by Sue Monk Kidd. Linguistics and Literature Journal, 1(1), 28-33.

Ulfa, Tutut Martha. (2016). The Metaphor used in Anne Bradstreet's Poems. Malang: Universitas Islam Negri Maulana Malik Ibrahim.

Unggul, Grace. M \& Gulo, Ingatan. (2017). An Analysis of Gerund and to Infinitive in Argumentative Essays. Teknosastik: Jurnal Bahasa dan Sastra, 15(1), 1-6.

Yousif, Marwan Khaleel. (2018). Relationship Between Everyday Language and Literary Language and Their Lasting Effects on the Learners of English https://www.researchgate.net/publication/324606622_Relationship_Between_Everyday_Language_and_Lit erary_Language_and_Their_Lasting_Effects_on_the_Learners_of_English_Language 